\title{
Combining Ability Analysis for Seed Cotton Yield and Its Component Traits in Cotton (Gossypium hirsutumL.)
}

\author{
B.B. Bilwal ${ }^{1 *}$, K.V. Vadodariya ${ }^{1}$, B.K. Rajkumar ${ }^{1}$, G.R. Lahane ${ }^{2}$ and N.D. Shihare ${ }^{2}$ \\ ${ }^{1}$ Main cotton Research Station (MCRS), Navsari Agricultural University, \\ Navsari, Gujarat, India \\ ${ }^{2}$ Vasantrao Naik Marathwada Agricultural University, Parbhani Maharashtra, India \\ *Corresponding author
}

\section{A B S T R A C T}

\begin{tabular}{|l|}
\hline K e y w o r d s \\
Cotton (G. hirsutum L.), \\
$\begin{array}{l}\text { Diallel, Combining } \\
\text { ability, gca, sca effect } \\
\text { and component traits }\end{array}$ \\
\hline Article Info \\
\hline $\begin{array}{l}\text { Accepted: } \\
\text { 24 June } 2018 \\
\text { Available Online: } \\
\text { 10 July } 2018\end{array}$ \\
\hline
\end{tabular}

\section{Keywords}

Cotton ( $G$. hirsutum L.) ability, and component traits

Article Info

Accepted:

Available Online:
The present study is aimed to estimate general combining ability of the parents and specific combining ability of hybrids for seed cotton yield and component traits. Combining ability analysis for seven characters was studied using diallel mating design involving 9 genotypes of cotton (Gossypium hirsutum L.). Combining ability analysis of variance revealed that non-additive gene action were important in the inheritance of various traits as evident from the significant of characters under study. Among the parents, GN.Cot-22, GJHV-337 and EC-10786 were the best general combiner for most of the characters under study. Six best combinations viz.,GJHV-337 x GN.Cot-22, GJHV-337 x EC-10786, GN.Cot-22 x KH-119, GN.Cot-22 x EC-10786, DELTA-15 x EC-10786 and GSHV-97/13 x GJHV-337 had high per se performance coupled with significant high sca can be exploited for hybrid vigour or to be utilized for the improvement of genotype.

\section{Introduction}

Cotton, the king of fibre, is one of the momentous and important cash crop exercising profound influence on economics and social affairs of the words and plays a vital role as a cash crop in commerce of many countries such as USA, China, India, Pakistan, Uzbekistan, Australia and Africa [1]. India is the pioneer country in the word for commercial exploitation of heterosis in cotton. With the success of first commercial cotton hybrid in 1971, main objective of breeder has been to develop high yielding hybrids through exploitation of heterosis [2]. The cotton belonging to the genus Gossypium (Malvaceae) comprises of approximately 50 species, distributed in various continents except Europe. It has four cultivated species: Gossypium hirsutum L., G. barbadense, G. arboreum L. and $G$. herbaceum L. The $G$. hirsutum species is the predominant cultivated cotton with high yield and wide adaptation, while its closely related species, $G$. barbadense is grown for its extra-long, strong, and fine fibre. The diploid species, $G$. arboreum L. and $G$. herbaceum L. are cultivated only in very small acreage [3]. Choice of parent for hybridization is the most important aspect, which depends not only on 
diversity of parents but also on combining ability as development of new variety with higher yield and fibre quality are the primary objectives of cotton breeding programmes. The first step in successful breeding programme is to select appropriate parents. Combining ability provides information for the selection of parents as well as the nature and magnitude of gene action involved in the expression of traits. The concept of combining ability was introduced by [4]. According to them general combining ability (gca) is average performance of a parent in a series of crosses and specific combining ability (sca) designates those cases in which certain combinations perform relatively better or worse than would be expected on the basis of average performance of lines involved. The variance of gca includes additive and additive $\mathrm{x}$ additive portions, while sca includes nonadditive genetic portion. Hence combining ability, which is important in the development of breeding procedures, is of notable use in crop hybridization either to exploit heterosis or to combine the favorable fixable genes. Development of new variety with higher yield and fibre quality are the primary objectives of cotton breeding programmes. The first step in successful breeding programme is to select appropriate parents. Diallel analysis provides a systemic approach for the identification of suitable parents and cross combination for the investigated traits. The general objectives of this study were to evaluate general combining ability of parents, specific combining ability of hybrids in cotton for yield, yield components traits and selecting superior hybrids that can be used in breeding programmes of cotton. The selection of superior parentsfor exploitation of hybrids vigour is most essential and the gca and sca may help in isolating desirable parents. The knowledge of combining ability provides a useful clue for selection of desirable parents for the development of better hybrids, which should be superior in yield, quality and resistance to biotic and abiotic stresses over the present cultivars. [5] Opined that high yielding lines may not necessarily be able to transmit their superiority to the offspring. Hence, to identify promising inbred line or parents and crosses, the present study was undertaken as also to study the general and specific combining ability effects.

\section{Materials and Methods}

Nine parental lines viz., GSHV-97/13, GJHV337, AET-5, GN.Cot-22, GSHV-97/1016, GISV-8/1029, DELTA-15, EC-10786 and KH119 were crossed in $9 \times 9$ diallel excluding reciprocal. Resultant thirty six cross combination alongwith nine parents were evaluated in randomized block design with three replication during kharif2015-16 at Main Cotton Research Station, (MCRS), NAU. Surat, Bharuch and Hansot considering three environments $E_{1}, E_{2}$ and $E_{3}$, respectively. Each entry was represented by single row plot of ten plants, spaced $120 \times 45 \mathrm{~cm}$. All the agronomic and plant protection measures were followed as per the recommended package of practices. Observations were recorded on five plants for the characters viz., seed cotton yield per plant, number of sympodia per plant, number of bolls per plant, bolls weight, seed index, ginning outturn and lint yield per plant. Combining ability analysis was carried out according to the model given by Model I, method II of[6].

\section{Results and Discussion}

\section{Combining ability variance}

The pooled analysis revealed significance of both general (gca) and specific (sca) combining ability variance for the traits under study which indicated that both the variances were important in inheritance of the characters (Table 1). However, variance due to sca were higher in magnitude than gca variance. It 
indicated that non-additive genetic variance was predominant. Specific combining ability is attributable to non-additive gene action, which may be due to dominance or epistasis or both and is non-fixable in nature. The presence of non-additive genetic variance is the primary justification for initiating the hybrid breeding programme [7]. Almost akin results have been reported by (8), (9) and (10). It was further observed that the variance due to environments were highly significant for all characters. The interaction, gca $x$ environments highly significant except sympodia per plant, seed index and seed cotton yield per plant. While, interaction, sca $x$ environments highly significant and magnitude was greater in former than later in all the characters. Suggesting greater influence of sca than the gca variance. (11) have also noticed higher variance due to sca than those of gca.

\section{Combining ability effects}

Based on estimates of general combining ability effects for various characters (Table 2), it was observed that none of the parents was found to be good general combiner for all the traits. However, an overall appraisal of general combining ability effects revealed that GJHV337, GN.Cot-22 and EC-10786 were observed to the best general combiner among nine parents for seed cotton yield and its component traits as well as parent GSHV97/13 alsofound good general combiner for boll weight as possessed significant and positive gca effects. In present investigation, parent viz., GJHV-337 and GN.Cot-22 exhibited high per se performance coupled with significant gca effect for majority of the characters. It was observed that among parents, i.e. EC-10786 (9.51), GN. Cot-22 (6.27) and GJHV-337 (5.73) exhibited significant positive gca effects for seed cotton yield/plant as well as high per se performance. It was also observed that the per se performance of different characters in general agreed with the gca effects. However, this cannot be taken as a rule because parents or genotypes with high per se performance need not always be good general combiners. This could be attributed due to the intra and/or inter-allelic interaction of genes concerned with the character modified by environmental factors (12). It was further observed (Table 2) that parents possessing good general combining ability for seed cotton yield per plant also possessed high general combining ability for one or more of its yield components. It appeared that per se performance as such may give an indication of the general combining ability of the parents involved in crosses. This suggested that while selecting the parents for hybridization programme per se performance of the parents should be given due consideration. Such parallel behavior of per se performance and general combining ability was also reported by [13], [14], [15] and [16]. The estimates of sca effects revealed that none of the hybrid was found consistently superior for all the traits. Out of thirty six hybrids, twelve hybrids exhibited significant and positive sca effects for seed yield per plant. The top three hybrids on the basis of significant positive sca effects and per se performance of seed yield per plant were GSHV-97/13 x KH-119 (20.28), GN.Cot-22 x KH-119 (18.80) and GJHV-337 x GN.Cot-22 (18.22) best sca effect for seed cotton yield per plant. These hybrids had also depicted significant positive sca effects for one or more of the yield attributing traits viz., Sympodia per plant, bolls per plant, boll weight, seed index, ginning outturn and lint yield per plant.

A perusal of sca effects revealed that 14 hybrids for lint yield per plant, ten for bolls per plant, nine for boll weight, ten for seed index and fourteen for ginning outturn expressed significant and positive sca effects. The highest significant sca effects in desired direction for component characters was 
exhibited by different hybrids viz., GJHV-337 x GN.Cot-22 (6.63), GJHV-337 x EC-10786 (5.68) and EC-10786 x KH-119 (5.35) for sympodia per plant; GJHV-337 x EC-10786 (9.89), GSHV-97/13 x GJHV-337 (8.49) and GJHV-337 x GN.Cot-22 (7.65) for number of bolls per plant; GSHV-97/13 x GJHV-337 (12.30), GJHV-337 x GN.Cot-22 (12.15) and EC-10786 x KH-119 (11.74) for boll weight; GJHV-337 x EC-10786 (9.19), GJHV-337 x GN.Cot-22 (8.89) and GN.Cot-22 x EC-10786 (7.37) for seed index; GJHV-337 x GN.Cot-22 (5.90), GSHV-97/13 x KH-119 (4.44) and GSHV-97/13 x GJHV-337 (4.10) for ginning outturn; GJHV-337 x GN.Cot-22 (15.18), GSHV-97/13 x KH-119 (13.15) and GJHV-
337 x EC-10786 (10.65) for lint yield per plant. These results are in accordance with those obtained by[17], [18] and [19]. The best three hybrids for seed yield per plant viz., GJHV-337 x GN.Cot-22 (good x good), GJHV-337 x EC-10786 (good $x$ good), GN.Cot-22 x KH-119 (good x average) and GN.Cot-22 x EC-10786 (good x good) had significant positive sca effects. High yielding hybrids also possessed high sca effects, high heterosis as well as high per se performance for most of its yield contributing characters. This appeared appropriate as yield being a complex character depends on a number of its component traits.

Table.1 Analysis of variance for seed cotton yield and its component traits in G. hirsutum L. cotton

\begin{tabular}{|c|c|c|c|c|c|c|c|c|}
\hline Source of variance & d.f. & $\begin{array}{c}\text { Sympodia } \\
\text { /plant }\end{array}$ & $\begin{array}{c}\text { Bolls/ } \\
\text { plant }\end{array}$ & $\begin{array}{c}\text { Boll weight } \\
(\mathrm{g})\end{array}$ & $\begin{array}{c}\text { Seed index } \\
(\mathrm{g})\end{array}$ & $\begin{array}{c}\text { Ginning } \\
\text { outturn } \\
(\%)\end{array}$ & $\begin{array}{c}\text { Seed cotton } \\
\text { yield /plant } \\
(\mathrm{g})\end{array}$ & $\begin{array}{c}\text { Lint yield/ } \\
\text { plant } \\
(\mathrm{g})\end{array}$ \\
\hline GCA & 8 & $106.74 * *$ & $107.30 * *$ & $87.07 * *$ & $127.90 * *$ & $46.16^{* *}$ & $149.22 * *$ & $134.02 * *$ \\
\hline SCA & 36 & $149.12 * *$ & $188.38 * *$ & $98.38^{* *}$ & $198.43 * *$ & $47.49 * *$ & $152.34 * *$ & $152.52 * *$ \\
\hline Environment (E) & 2 & $160.16 * *$ & $1202.43 * *$ & $596.37 * *$ & $1332.99 * *$ & $125.01 * *$ & $3225.13 * *$ & $538.74 * *$ \\
\hline GCA x E & 16 & 5.85 & $24.32 * *$ & $16.53 * *$ & 24.06 & $5.01 * *$ & 52.83 & $17.64 * *$ \\
\hline SCA x E & 72 & $6.39 * *$ & $27.97 * *$ & $21.85 * *$ & $30.15 * *$ & $6.45 * *$ & $81.36 * *$ & $18.99 * *$ \\
\hline Error & 264 & 3.71 & 11.53 & 10.44 & 15.24 & 1.97 & 35.53 & 6.17 \\
\hline
\end{tabular}

$*$ and $* *=$ Significant at $5 \%$ and $1 \%$ levels of probability, respectively

Table.2 Estimation of general combining ability (gca) effect seed cotton yield and its component traits in cotton $(G$. hirsutum L)

\begin{tabular}{|c|c|c|c|c|c|c|c|c|}
\hline $\begin{array}{l}\text { Sr. } \\
\text { No. }\end{array}$ & Parents & $\begin{array}{l}\text { Sympodia } \\
\text { /plant }\end{array}$ & $\begin{array}{l}\text { Bolls/ } \\
\text { plant }\end{array}$ & $\begin{array}{c}\text { Boll } \\
\text { weight } \\
\text { (g) }\end{array}$ & $\begin{array}{c}\text { Seed } \\
\text { index } \\
(\mathrm{g})\end{array}$ & $\begin{array}{c}\text { Ginning } \\
\text { outturn } \\
(\%)\end{array}$ & $\begin{array}{l}\text { Seed cotton } \\
\text { yield /plant } \\
\text { (g) }\end{array}$ & $\begin{array}{l}\text { Lint yield/ } \\
\text { plant } \\
(\mathrm{g})\end{array}$ \\
\hline 1. & GSHV-97/13 & $-1.56 * *$ & $-2.20 * *$ & $0.19 * *$ & 0.42 & -0.09 & $-2.61 * *$ & $-2.54 * *$ \\
\hline 2. & GJHV-337 & $2.82 * *$ & $2.68 * *$ & $1.71 * *$ & $3.35 * *$ & $1.66 * *$ & $5.73 * *$ & $3.28 * *$ \\
\hline 3. & AET-5 & $-1.33 * *$ & -0.73 & $-1.31 *$ & -0.77 & $-1.59 * *$ & $-4.44 * *$ & 0.26 \\
\hline 4. & GN.Cot-22 & $1.86 * *$ & $2.80 * *$ & $3.78 * *$ & $1.39 *$ & $0.76 * *$ & $6.27 * *$ & $3.10 * *$ \\
\hline 5. & GSHV-97/1016 & $-0.91 * *$ & -0.91 & $-2.26 * *$ & $-2.02 * *$ & $-1.07 * *$ & $-5.10 * *$ & $-1.72 * *$ \\
\hline 6. & GISV-8/1029 & $-1.04 * *$ & -0.89 & $-3.14 * *$ & $-1.95 * *$ & $-0.79 * *$ & $-5.37 * *$ & $-2.46 * *$ \\
\hline 7. & DELTA-15 & $-2.02 * *$ & $-1.65 * *$ & $-1.10 *$ & $-2.59 * *$ & $-0.63 * *$ & $-3.10 * *$ & $-2.85 * *$ \\
\hline 8. & EC-10786 & $2.07 * *$ & 1.10 & $3.06 * *$ & $1.31 *$ & $1.77 * *$ & $9.51 * *$ & $3.99 * *$ \\
\hline 9. & КН-119 & 0.11 & -0.20 & -0.94 & 0.87 & -0.01 & -0.89 & $-1.07 * *$ \\
\hline & S.E.(gj) & 0.32 & 0.56 & 0.53 & 0.64 & 0.23 & 0.98 & 0.39 \\
\hline
\end{tabular}

$*$ and $* *=$ Significant at $5 \%$ and $1 \%$ levels of probability, respectively 
The perusal of data (Table 1 and 2) revealed that good general combining parents may not necessarily always produce good specific combinations for different traits. In many cases, it was observed that at least one good general combining parents was involved in heterotic hybrid having desirable sca effects. Similar results in cotton were also reported by [20] and [21]. This suggested that information of gca effects of parents should be considered along with sca effects and per se performance of hybrid for predicting the value of any hybrid. It is desirable to search out parental lines with high gca effects and low sensitivity to environmental variation in a crop improvement programme.

In a view of per se performance of parents and their gca effects for seed yield per plant and other characters studied among the parents, GN.Cot-22, GJHV-337 and EC-10/786 were the best general combiner for most of the characters under study. Six best combinations viz., GJHV337 x GN.Cot-22, GJHV-337 x EC-10/786, GN.Cot-22 x KH-119, GN.Cot-22 x EC-10/786, DELTA-15 x EC-10/786 and GSHV-97/13 x GJHV-337 had high per se performance coupled with significant high sca can be exploited for hybrid vigour or to be utilized for the improvement of genotype were identified as the most promising parents and hybrids hence they could be used extensively in breeding programme for improving seed cotton yield per plant in cotton. Similar results have been reported by [22] and [23].

A combination of poor combiners also gives several crosses with high and significant sca effects across the traits, such crosses could be expected to through up some transgressive segregants in recurrent selection. A progeny selection with pedigree method in such crossesmay through up transgressive segregants leading to development of good inbreds.

\section{References}

1. Anderson, CG. (1999). Cotton marketing. In: Smith, C.W, Cothren,
J.T. (eds) Cotton: Origin, History, Technology and Production. Wiley, New York, pp: 659-679.

2. Patel, C T. (1971) Hybrid 4-A new hope towards self-sufficiency in cotton in India. Cotton Development, 1(2): 1-6.

3. Wendel, JF and Cronn, RC. (2003). Polyploidy and the evolutionary history of cotton. Journal of Advances in Agronomy, 78: 139-186.

4. Sprague, GF and Tatum, LM. (1942). General versus specific combining ability in single crosses of corn. Agronomical Journal, 34: 923-932.

5. Allard, RW. (1960). "Principles of Plant Breeding". John Willy and Sons, New York. p. 485.

6. Griffings, B. (1956). Concept of general and specific combining ability in relation to diallel crossing system. Australian Journal of Biological Science, 9: 463-493.

7. Cockerham, CC. 1961. Implication of genetic variances in a hybrid breeding programme. Crop Science, 1: 47-52.

8. Pratap, LK, Reddy, CV, Reddy, KVS and Rao, PC. (2006). Combining ability for yield component traits in cotton. Andhra Agriculture Journal, 53 (3\&4): 152- 156.

9. Patel, AD, Patel, UG and Kumar, V (2009). Diallel analysis for heterosis and combining ability for seed cotton yield and its component traits in upland cotton. Journal of Cotton Research and Development, 23: 222-225.

10. Rajmani, S, Gopinath, $\mathrm{M}$ and Reddy, KPH. (2014). Combining ability for seed cotton yield and fibre characters in upland cotton (Gossypium hirsutum L.). Journal of Cotton Research and Development, 28(2): 207-210.

11. Khorgade, PW, Satange, LV and Pillai B. (2000). Heterosis and combining ability for cotton yield and its components in American cotton. Agricultural Science and Digest, 20(2): 131-132.

12. Dabholkar, AR. (1999). Elements of 
Biometrical Genetics. Concept Publishing Company, New Delhi. pp: 248.

13. Ahmad, RD, Malik, AJ, Gul, H and Subhan, M. (2005). Estimation of combining ability for seed cotton yield and its components in inter-varietal crosses of cotton (Gossypium hirsutum L.). Gomal University Journal of Research, 21: 1-6.

14. Elangaimannan, R, Anbuselvam, Y, Venkatesan, $M$ and Karthikeyan, $P$. (2007). Diallel analysis in cotton (Gossypium hirsutum L.). International Journal of Plant Science, 2: 53-56.

15. Patil, SA, Naik, MR and Patil, AB. (2011). Line $\mathrm{x}$ tester analysis for seed cotton yield and fibre quality traits in (Gossypium hirsutum L.). Plant Archives, 11(1): 525-528.

16. Kumar, M, Nirania, KS, Sangwan, RS, Yadav, K and Prakash, S. (2014). Combining ability for seed cotton yield and its contributing traits in upland cotton (Gossypium hirsutum L.) Journal of Cotton Research and Development, 27: 11-15.

17. Pandit, SP, Lodam, VA, Sakhare, BA and Wandhare, MR. (2014). Genetic architecture for seed cotton yield and fibre quality trait in upland cotton (Gossypium hirsutum L.). Journal of Cotton Research and Development, 28 (2): 201-203.

18. Srinivas, B and Bhadru, D. (2015). Combining ability studies for yield and fibre quality traits in upland cotton (Gossypium hirsutum L.). SABRO Journal of Breeding and Genetics,46 (2): 313-318.

19. Dave, PB, Patil, BN, Patel, PC, Patel, MP and Patel, NA. (2015). Study of combining ability analysis and gene action for seed cotton yield and its agronomic trait in upland cotton. Journal of Cotton Research and Development, 28(2): 212-219.

20. Tuteja, OP, Kumar, S, Verma, SK and Ahuja, S. (2004). Estimation of combining ability for seed cotton yield and its component characters in Gossypium hirsutum L. Journal of Cotton Research and Development, 18(1): 38-41.

21. Natera, MV, Laghari, SL, Soomro, ZA and Abro, S. (2012). Combining ability for seed cotton yield and its component traits in upland cotton. Journal of Cotton Research and Development, 23: 222-225.

22. Hussein, SB, Javad, M, Zuber, $M$ and Ahemad, N. (2013). Gene action in the inheritance of agronomic traits in diallel crosses of Gossypium hirsutum L., Journal of Animal and Plant Science, 23(3): 849-853.

23. Khan, SA, Khan, MU, Gul, R, Khan, IU, Gul, S. Ali, S and Baloch, M. (2015). Combining ability for yield and fibre traits in upland cotton. Journal of Animal and Plant Science, 25(3): 698707.

\section{How to cite this article:}

Bilwal, B.B., K.V. Vadodariya, B.K. Rajkumar, G.R. Lahane and Shihare, N.D. 2018. Combining Ability Analysis for Seed Cotton Yield and Its Component Traits in Cotton (Gossypium hirsutumL.). Int.J.Curr.Microbiol.App.Sci. 7(07): 3005-3010. doi: https://doi.org/10.20546/ijcmas.2018.707.351 